\title{
Empirical Test of Fama and French Three-Factor Model in the Egyptian Stock Exchange
}

\author{
Mustafa Hussein Abd-Alla', Mahmoud Sobh' ${ }^{2}$ \\ ${ }^{1}$ Sadat Academy for Management Sciences \\ Department of Business Administration \\ Cairo, Egypt \\ Email: m haa60@yahoo.com \\ 2 Ain Shams University \\ Faculty of Commerce \\ Cairo, Egypt
}

\begin{abstract}
We test the empirical validity of the three-factor model of Fama and French in the Egyptian Stock Exchange (EGX) using monthly excess stock returns of 50 stocks listed on the EGX from January 2014 to December 2018. Our findings do not support Fama and French three-factor model, where the coefficient of the beta was insignificant. The "SBM" coefficient and the "HML" coefficient were equal to zero and insignificant, which confirms the absence of the small firm effect and book-to-market ratio effect in the market. We conclude that there is no relation between expected return and Fama-French risk factors.
\end{abstract}

Keywords: Fama and French three-factor model, Value Effect "HML", Size Effect "SBM", Market Beta, Egyptian Stock Exchange.

JEL code: $G 12$

\section{Introduction}

The capital assets pricing model (CAPM) developed by Sharpe (1964) and Lintner (1965) aims to answer the question how we can price securities taking into consideration the risk and the return; this principle was developed by Harry Markowitz (1952). However, this model takes into account only one risk factor to show that variation in excess returns: the market beta, which reflects the sensitivity to excess market portfolio return (Market premium). A lot of research has been done to test the validity of the CAPM. However, these studies results provide no evidence to support the validity of the CAPM model (Ross 1976; Chen et al. 1986; Khudoykulov et al. 2015; Alqisie and Alqurran 2016; and Hussain and UI Islam 2017).

The size effect is one of the market anomalies in the pricing of assets; it was first discovered by Banz (1981) and Reinganum (1981). They concluded that the firm size is a representation of risk. Fama and French (1992) and Lakonishok et al. (1994) concluded that there is a strong value premium in average returns. Based on the results of their previous studies, Fama and French (1993) concluded that the variation in stock returns could be explained by three risk factors. These factors are the market beta coefficient, the size of the firm, and book-to-market 
equity ratio. Fama and French constructed a model known in the finance literature as the Fama and French three-factor model, which is used for explaining the variation in stock returns by employing these three factors as the explanatory variables.

The lack of a theoretical basis of the empirically identified factors in the threefactor model raises questions about their generality and their ability to explain the relationship between returns and risk on different markets and periods. Different capital market regulations, systems of corporate governance, and different investor behaviours may have an important impact on the significance of risk factors in the three-factor model. Consequently, these relationships need to be analysed in different financial markets to see to what extent they are applicable. Because of the scarcity of studies that have dealt with different pricing models and the role of the beta factor, the size and value factor in explaining the relationship between return and risk in the EGX, this study aimed to investigate the validity of the Fama and French three-factor model (1993) in the EGX from January 2014 to December 2018. This study also aims to investigate the presence of the size and value effect in the EGX. Investors need to identify the factors affecting portfolio returns, so this study aims to test whether the three factors in the Fama and French three-factor model (1993) are valid indicators to evaluate and construct portfolios; this makes evaluation of risk and return of a specific portfolio more efficient.

The study will be organized as follows. In section 1 we will provide a survey of the literature. In section 2 we will present the data and methodology. Section 3 presents empirical results, and finally, we will provide the conclusions in Section 4.

\section{Literature Review}

Sharpe (1964) and Lintner (1965) developed the Capital Asset Pricing Model (CAPM); it was built on the work of Harry Markowitz (1959), who developed the "mean-variance model". The CAPM model proposed a positive linear relationship between the expected risk of the asset and its expected rate of return. The only related risk measure is systematic risk, which is measured through beta. Beta estimates how the rate of returns on the shares or portfolio will move relative to the movements in the market portfolio.

In their early study, Fama and French (1992) used a sample of non-financial stocks listed on the NYSE, NASDAQ, and AMEX from 1963 to 1990 . They examined the ability of the market beta coefficient, size of the firm, book to market equity ratio, Earnings/Price ratio (E/P), and leverage to predict the stock returns. They found no relationship between the market beta factor and the stock returns; they also found that stocks with high book-to-market equity ratios (value stocks) and small stocks have high returns compared to stocks with low book-to-market equity ratios (growth stocks) and big stocks.

Fama and French (1993) provided a different perspective on capital asset pricing 
models. This study aimed to explain the relation between expected excess returns and the market premium as well as the value factor measured by the book-tomarket equity ratio, which is calculated by taking the average excess return on a portfolio with a high ratio of book-to-market stocks minus the average excess return on a portfolio with a low ratio of book-to-market stocks, and company size measured by market capitalization, which is calculated by taking the average return on the portfolios with small market capitalization stocks minus the average return on the portfolios with big market capitalization stocks. Fama and French (1993) expanded the study to include the U.S government and corporate bonds in addition to stocks. They confirmed that portfolios created based on a market factor, book-to-market equity (BE/ME) and size have important effects on stock returns, where Fama and French three-factor model (1993) is successful in the explanation of the cross-section of average returns on U.S. stocks. Their model can be written as:

$$
R_{i t}-R_{f}=b_{i}\left[R_{m t}-R_{f}\right]+s_{i}[S M B]+h_{i}[H M L]
$$

Where:

- $\quad$ Rit is the expected return on asset $i$ at time $t$;

- $\quad R_{f}$ is the risk-free rate;

- $\quad \mathrm{R}_{\mathrm{mt}}-\mathrm{R}_{\mathrm{f}}$ is the expected excess return of the market portfolio at period $t$;

- $\quad$ SMB is the expected return of the size factor (proxy for company size);

- HML is the expected return on the book-to-market value (BE/ME) factor (proxy for company value);

- $\quad b i, s i, h i$ are the coefficients (betas) of the three independent variables $\mathrm{R}_{\mathrm{mt}}-$ $\mathrm{R}_{\mathrm{f}}, \mathrm{SMB}$ and $\mathrm{HML}$.

Fama and French (1995) analyzed the characteristics of companies with high book-to-market equity and those with low book-to-market equity. They examined all stocks listed on U.S. national exchanges (AMEX, NYSE and NASDAQ) from 1963 to 1992. .They showed that companies that have a high book-to-market equity ratio (value stocks) are associated with persistently low earnings and companies that have a low book-to-market equity ratio (growth stocks) are associated with persistently strong earnings.

Daniel and Titman (1997) used monthly data for firms listed on NYSE, AMEX and NASDAQ stock markets from July 1963 to December 1993 to test the Fama and French three-factor model's explanatory power. Their results are not compatible with Fama and French three-factor model (1993), as they found that there is no relation between the expected rate of return and risk factors in Fama and French three-factor model (1993). They showed that the high returns on stocks with small market capitalization and high book-to-market equity ratios (value stocks) cannot be viewed as risk compensation. They also showed that investors like (growth stocks) stocks with low book-to-market equity ratios (strong firms) and dislike (value stocks) stocks with high book-to-market equity ratios (weak firms). 
They also found no relationship between the market beta factor and the stock returns.

Mohanty (2002) used the same methodology as Fama and MacBeth (1973) to determine which of the characteristics of the firms such as size, value and financial leverage can explain the difference in the return through cross-sectional analysis for all stocks listed on the Indian Stock Exchange from September 1991 to March 2000. The number of stocks in the sample differed from 762 stocks in 1991 to 1971 stocks in 1999, and the maximum sample reached 3270 stocks in 1997 . He concluded that the relationship between the size of the firm and the expected return is a strong negative relationship and the return on small stocks exceeds the return on large stocks by up to $70 \%$. He also found that the relationship between book-to-market equity ratios and expected return is also negative.

Gaunt (2004) studied the three-factor model in the Australian Securities Exchange from July 1991 to June 2000 for a sample of 6814 companies. The sample was divided into 25 portfolios formed by size and value. They found that the beta coefficient was statistically significant: the beta coefficient was large for small firms and firms with low book-to-market-equity (BE/ME). The study also found that the Frama and French three-factor model provided a better explanation than the CAPM model for the Australian Stock Exchange.

Novak (2011) analyzed the ability of the size, value and the systemic risk coefficient (beta) to predict Swedish stock returns from 1979 to 2005 for a sample of 609 stocks by using monthly data on stock returns. The study used the same methodology as Fama-MacBeth (1973). The rate of return on government bonds was also used as a proxy for the risk-free rate. He found that all the risk factors under study are not statistically significant and cannot predict Swedish stock returns, which casts doubt on use as global risk factors.

Mehta \& Chande (2010) used monthly returns for a sample of 219 stocks listed on the Indian stock market from February 1999 to December 2007 to test the ability of the Fama and French three-factor model (1993) to explain the cross-section of expected stock returns. They found that the Fama and French three-factor model (1993) was very statistically significant in explaining the cross-section variance of expected returns. They also found that the size and value factors (SMB \& HML) are not sufficient to explain the cross-section variance of expected returns either individually or jointly with each other, but when the market factor (RM-RF) combined with the size and value factors ( $S M B \& H M L$ ) is used, the explanatory power of the model increases. The results showed that the explanatory power of the (RM-RF) individually was greater than the explanatory power of the total size and value.

Mazviona \& Nyangara (2014) used the same methodology as Banz (1981) to examine the relationship between the size of the company and stock returns listed on the Zimbabwe Stock Exchange from June 2009 to July 2013. The sample consisted of 64 firms listed on the Zimbabwe Stock Exchange. They found that the size factor is not statistically significant at $5 \%$, so the size of the firm has no impact 
on the stock returns listed on the Zimbabwe Stock Exchange. The study also found that, contrary to the general empirical results, large firms have higher risk levels than small size firms, so the return on large firms is higher than the return on small firms.

Shaker and Elgiziry (2014) studied the applicability of the Fama and French threefactor model (1993) for 55 shares listed on the EGX100 in the Egyptian stock market from January 2003 to December 2007. They confirmed the ability of the Fama and French three-factor model (1993) to capture the cross-section of average returns in the Egyptian stock market.

Shaker and Abdeldayem (2018) used monthly data for all companies listed on the EGX 100 to examine the ability of the Fama and French three-factor model (1993) and CAPM model to explain the cross-section of expected stock returns in the Egyptian stock exchange from January 2003 to December 2007. They found that the explanatory power increased after adding the size factor (SMB) and value factor (HML) to the CAPM model, where the average value of $\left(R^{2}\right)$ increases from $30 \%$ to $57.15 \%$. The study also found the existence of the size effect in the Egyptian stock exchange.

Wang (2018) empirically examined the ability of the Fama and French three-factor model (1993) to explain the cross-section of expected stock returns in the Taiwan stock market by using monthly data from July 1982 to December 2012. They found that the coefficient of determination $\left(R^{2}\right)$ for the six portfolios ranged from $93 \%$ to $97 \%$, which indicates a great ability to explain the cross-section of expected stock returns.

Ragab et al. (2019) examined the ability of the Fama and French three-factor model (1993) to explain the cross-section of expected stock returns in the Egyptian stock exchange from July 2005 to June 2016. They found that the Fama and French three-factor model (1993) can well capture the variations in stock returns related to the BE/ME ratio and size factor. The study also found the existence of the size effect; however, the results found the absence of value effect in the Egyptian market.

Dirkx and Peter (2020) studied the three-factor model in the German market using monthly data from 2002 to 2019. They confirmed the ability of the Fama and French three-factor model (1993) to capture the cross-section of average returns. The study also found the existence of the size and value effect in the German market.

\section{Data and Methodology}

\subsection{Data}

This study used monthly data for a sample of firms listed on the EGX from January 2014 to December 2018 to examine the performance of the Fama and French three-factor model (1993) and to investigate the presence of size and value effect in the EGX. These data included: 
- monthly stock returns;

- monthly returns of the EGX100 index, which is used as a proxy for the market portfolio. EGX100 index is a price index that measures the performance of the 100 active companies in the EGX, including both the 30 companies of EGX 30 Index and the 70 companies of EGX 70 Index;

- monthly returns on the Postal Savings used as a proxy for the risk-free rate;

- data on book values of equity extracted from annual financial statements.

Not all stocks are chosen for testing the Fama and French three-factor model (1993). The following conditions have to be met:

- Stocks should be listed on the EGX100 index.

- The trading currency on the stock should be the Egyptian pound.

- Stocks of banks and financial institutions are excluded because their specific liability and asset structure usually produce high financial leverage, which prevents the comparability of their book-to-market equity ratios with those of non-financial firms.

- Availability of stock prices for a continuous 60 months.

- The ratio of the book value to the market value should be positive.

The number of stocks satisfying the test conditions is 50 shares listed on the EGX100 index in the EGX.

\subsection{Methodology}

To mimic the common risk factors of size and book-to-market equity, we used the Fama and French (1993) approach to construct six portfolios sorted according to market capitalization and book-to-market equity. Fama and French form size and book-to-market equity portfolios to describe the cross-sectional variation in the average stock rate of returns.

\section{Portfolios Construction}

We used the same methodology as Fama and French (1993) to construct the SMB (Small Minus Big) and HML (High Minus Low) factors; all stocks in the sample are ranked based on the firm size (market capitalization as of June of each year $t$ ). Stocks are sorted into two portfolios by using the median sample size (Big - B and Small - S) according to the split point, which is $50 \%$, where the highest $50 \%$ stocks according to size are big and the lowest 50\% stocks according to size are small.

The sample stocks are also ranked by book-to-market equity, where the stocks are divided into 3 portfolios according to book-to-market equity ratio. The first portfolio, $30 \%$ of whole sample stocks, has the highest book-to-market equity ratio (High: $\mathrm{H}$ group). The second portfolio, $40 \%$ of whole sample stocks, has a medium book-to-market equity ratio (Medium: M group); and the third portfolio, $30 \%$ of whole sample stocks, has the lowest book-to-market equity ratio (Low: L group). 
Six portfolios ( $\mathrm{SL}, \mathrm{SM}, \mathrm{SH}, \mathrm{BL}, \mathrm{BM}, \mathrm{BH}$ ) are constructed based on the intersection of the tow size and three $\mathrm{BE} / \mathrm{ME}$ portfolios, where:

- $\quad$ SH portfolio with small size and high book-to-market equity ratio;

- $\quad$ SM portfolio with small size and medium book-to-market equity ratio;

- $\quad$ SL portfolio with small size and low book-to-market equity ratio;

- $\quad$ BH portfolio with big size and high book-to-market equity ratio;

- $\quad$ BM portfolio with big size and medium book-to-market equity ratio;

- $\quad$ BL portfolio with big size and low book-to-market equity ratio.

SMB (small minus big) is the difference of returns on a small stocks portfolio and a big stocks portfolio, and it was calculated using the following equation:

$$
S M B=\frac{R(S L+S M+S H)-R(B L+B M+B H)}{3}
$$

Where $\mathrm{R}(\mathrm{SL}+\mathrm{SM}+\mathrm{SH})$ is the expected return on $(\mathrm{SL}+\mathrm{SM}+\mathrm{SH})$ portfolio, and $\mathrm{R}$ $(B L+B M+B H)$ is the expected return on $(B L+B M+B H)$ portfolio.

$\mathrm{HML}$ (high minus low) is the difference of returns on high book-to-market value (BE/ME) stocks portfolio and on a portfolio of low (BE/ME) stocks and it was calculated using the following equation:

$$
H M L=\frac{R(S H+B H)-R(S L+B L)}{2}
$$

Where $R(S H+B H)$ is the expected return on $(S H+B H)$ portfolio, and $R(S L+B L)$ is the expected return on $(S L+B L)$ portfolio.

\section{The Model}

Fama and French (1993) developed three-factor asset pricing model for stocks to explain the relation between expected excess returns $\left[R_{i t}-R_{f}\right]$, the excess market return (RM-RF) and two additional risk factors related to the value factor (HML) and the size factor (SMB). To estimate the parameters in the Fama and French three-factor model we used the two-pass cross-sectional regression method. The first step is to employ a time-series regression of the excess return of the sample stocks on excess market return, HML and SMB using the following model:

$$
R_{i t}-R_{f}=a_{i}+b_{i}\left[R_{m t}-R_{f}\right]+s_{i}[S M B]+h_{i}[H M L]+\varepsilon_{i t}
$$

Where:

- $\quad R_{i t}$ is the expected return on asset $i$ at time $t$;

- $R_{f}$ is the risk-free rate;

- $R_{m t}-R_{f}$ is the expected excess return of the market portfolio at period $t$;

- $\quad$ SMB is the expected return of the size factor (a proxy for company size);

- $\quad$ HML is the expected return on the book-to-market value factor (a proxy for company value);

- $\quad b i, s i, h i$ are the coefficients (betas) of the three independent variables; 
- $\quad a i$, cit are the intercept and the error term, respectively.

The second step is to run the following cross-sectional regression:

$$
r_{i}=\gamma_{0}+\gamma_{1} b_{i}+\gamma_{2} s_{i}+\gamma_{3} h_{i}+\varepsilon_{i t}
$$

Where:

- $\quad r_{i}$ is the average excess return for the stock i over the whole sample;

- $\gamma_{0}, \gamma_{1}, \gamma_{2}$, and $\gamma_{3}$ are the parameters that we will be estimated;

- $\quad b_{i}$ is the estimated coefficients (betas) of the expected excess return of the market portfolio;

- $\quad s_{i}$ is the estimated coefficients (betas) of the size factor (SMB);

- $h_{i}$ is the estimated coefficients (betas) of the value factor (HML).

\section{Empirical Results}

\subsection{Summary Descriptive Statistics}

Table 1 presents the descriptive statistics of the excess stock return, excess market portfolio return, size factor (SMB), and the value factor (HML).

Table 1 Descriptive Statistics of the Excess Stock Return, Excess Market Portfolio Return, Size Factor (SMB), and the Value Vactor (HML)

\begin{tabular}{lcccc}
\hline & $\begin{array}{c}\text { Rit- Rf } \\
\text { Excess } \\
\text { Stock return }\end{array}$ & $\begin{array}{c}\text { RM-Rf } \\
\text { Excess market } \\
\text { return }\end{array}$ & HML & SMB \\
\hline \hline Mean & -0.08 & -0.08 & 0.00 & -0.01 \\
\hline Std. Error & 0.00 & 0.01 & 0.01 & 0.01 \\
\hline Median & -0.08 & -0.08 & 0.00 & -0.01 \\
\hline Std. Dev. & 0.01 & 0.07 & 0.05 & 0.04 \\
\hline Variance & 0.00 & 0.00 & 0.00 & 0.00 \\
\hline Kurtosis & 0.66 & 4.82 & 2.58 & 1.23 \\
\hline Skewness & 0.60 & I.30 & 0.01 & 0.18 \\
\hline Minimum & -0.11 & -0.22 & -0.14 & -0.12 \\
\hline Maximum & -0.04 & 0.22 & 0.17 & 0.11 \\
\hline
\end{tabular}

Source: Author's construction

$\left(R_{i t}-R_{f}\right)$ is the excess stock return. $\left(\mathrm{R}_{\mathrm{mt}}-R_{f}\right)$ is the excess return on the market portfolio. SMB is the excess return of small stocks portfolio compared to large stocks portfolio per month. HML is the excess return of stocks with high BE/MEratio compared to firms with low BE/ME-ratio per month. The results show that the mean return of firm size factor (SMB) equals $(-0.01)$, which indicates that portfolios with big market capitalization outperform portfolios with small market capitalization and this is in conflict with the three-factor model. The results also 
show that the mean return of the value factor ( $\mathrm{HML}$ ) equals zero; this indicates that there is no difference between the return on the portfolio with high BE/MEratio and the portfolio with low BE/ME-ratio, and this is in conflict with the threefactor model, which states that the stocks with high book-to-market equity ratios (value stocks) have high returns compared to stocks with low book-to-market equity ratios (growth stocks).

Table 2 presents the descriptive statistics for the six portfolios based on Fama and French three-factor model ( $\mathrm{SL}, \mathrm{SM}, \mathrm{SH}, \mathrm{BL}, \mathrm{BM}$ and $\mathrm{BH})$.

Table 2 Descriptive Statistics for the Six Portfolios of Fama and French Threefactor Model (1993)

\begin{tabular}{lcccccc}
\hline & BH & BM & BL & SH & SM & SL \\
\hline \hline Mean & 0.015 & 0.013 & 0.016 & 0.01 & 0.009 & 0.008 \\
\hline Std. Error & 0.011 & 0.013 & 0.011 & 0.012 & 0.012 & 0.011 \\
\hline Median & 0.002 & 0.010 & 0.002 & 0.002 & 0.001 & -0.005 \\
\hline Std. Dev. & 0.086 & 0.098 & 0.088 & 0.090 & 0.096 & 0.087 \\
\hline Variance & 0.007 & 0.010 & 0.008 & 0.008 & 0.009 & 0.008 \\
\hline Kurtosis & 3.975 & 1.296 & 7.243 & 0.702 & 1.685 & 2.505 \\
\hline Skewness & 1.099 & 0.627 & 1.958 & 0.463 & 0.947 & 1.196 \\
\hline Minimum & -0.194 & -0.180 & -0.122 & -0.212 & -0.170 & -0.151 \\
\hline Maximum & 0.356 & 0.321 & 0.427 & 0.263 & 0.343 & 0.300 \\
\hline
\end{tabular}

Source: Author's construction

Results show that there is a slight superiority in the performance of large-size portfolios compared to small-size portfolios, Where the mean of the average return on small portfolios ( $\mathrm{SL}, \mathrm{SM}$ and $\mathrm{SH})$ is equal to $(0.008,0.009,0.01)$ with a standard deviation equal to $(0.087,0.096,0.090)$ respectively, while the mean of the average return on big portfolios $(\mathrm{BL}, \mathrm{BM}$ and $\mathrm{BH})$ is equal to $(0.016,0.013,0.015)$ with a standard deviation equal to $(0.088,0.098,0.086)$ respectively, and this conflicts with the Fama and French three-factor model (1993), which states that the small stocks have high returns compared to big stocks.

Table 3 shows the correlation between Fama and French three risk factors portfolios. Excess market portfolio return (Rm-Rf) is negatively correlated with both HML and SMB portfolio returns and this correlation is weak. SMB and HML portfolios also negatively correlated and this correlation is weak, which implies that the variation in one of the variables has a weak effect on the other variables' estimation. 
Table 3 Correlation between Fama and French Three Risk Factors Portfolios

\begin{tabular}{lccc}
\hline & RM-RF & HML & SMB \\
\hline \hline RM-RF & 1.000 & -0.010 & -0.080 \\
\hline HML & -0.010 & 1.000 & -0.150 \\
\hline SMB & -0.080 & -0.150 & 1.000 \\
\hline
\end{tabular}

Source: Author's construction

Table 4 shows the correlation between (market premium (beta), HML and SBM) and the excess stock return. The results show that the relationship between the excess stock return and both $\mathrm{HML}$ and market premium was found negative and insignificant. Also, the relationship between the excess stock return and SMB was found positive and insignificant, which implies that the variation in market premium, HML and SBM variables do not affect the excess stock return estimation.

Table 4 Correlation between (Market Premium (Beta), HML and SBM) and the Excess Stock Return

\begin{tabular}{cccccccc}
\hline & \multicolumn{2}{c}{ Market premium } & \multicolumn{2}{c}{ HML } & \multicolumn{2}{c}{ SMB } \\
\cline { 2 - 7 } & Correlation & sig & Correlation & sig & Correlation & sig \\
\cline { 2 - 7 } $\begin{array}{c}\text { Excess stock } \\
\text { return }\end{array}$ & -0.115 & 0.428 & -0.171 & 0.236 & 0.206 & 0.151 \\
\hline
\end{tabular}

Source: Author's construction

\subsection{Regression Results}

Table 5 shows the regression results of the Fama and French three-factor model (1993) in the EGX from January 2014 to December 2018. The results show that Adjusted R Square equals $0.1 \%$, so $99.9 \%$ of the return changes are due to factors other than risk factors in the model. This indicates that the explanatory power of the risk coefficients in the Fama and French three-factor model (1993) is very weak. The intercept was found negative and significant; if the intercept is negative, the asset achieved a return lower than it should have given its risk level; this indicates that there is a pricing error in the specifications of the model, where the intercept should be equal to zero. The slope of the market premium (beta) was positive and insignificant with t-statistics equal to 0.889 , so the market risk premium is not a determinant of the required rate of return for stocks. The "SBM" coefficient was insignificant and equaled zero with t-statistics of -1.387 , which confirms the absence of the small firm effect. Moreover, the "HML" coefficient was equal to zero and insignificant with t-statistics of 0.297 , which provides evidence that the book-to-market ratio effect does not exist in the market. The results also show that the regression model is not significant, as the p.value is 0.394 , which indicates the inability of the risk factors in the model to predict changes in stock returns in the EGX. All these results do not support Fama and French three-factor 
model (1993) findings. This is an indication that the Fama and French three-factor model (1993) cannot explain excess stock returns in the EGX.

Table 5 Regression Results of the Fama and French Three-factor Model (1993)

\begin{tabular}{|c|c|c|c|c|c|c|c|}
\hline D7+A1:A1:H11 & $\begin{array}{l}\text { Sum of } \\
\text { Squares }\end{array}$ & df & $\begin{array}{l}\text { Mean } \\
\text { Square }\end{array}$ & $\mathbf{F}$ & Sig. & $\mathbf{R}$ & $\begin{array}{l}\text { Adjusted } \\
\text { R Square }\end{array}$ \\
\hline Regression & 0 & 3 & 0 & & & & \\
\hline Residual & 0.007 & 46 & 0 & 1.017 & 0.394 & 0.249 & 0.001 \\
\hline Total & 0.008 & 49 & & & & & \\
\hline
\end{tabular}

Coefficients

\begin{tabular}{cccccc}
\hline & \multicolumn{2}{c}{$\begin{array}{c}\text { Unstand. } \\
\text { Coefficients }\end{array}$} & $\begin{array}{c}\text { Stand. } \\
\text { Coefficients }\end{array}$ & \multirow{2}{*}{ t } & Sig. \\
\cline { 2 - 5 } & B & $\begin{array}{c}\text { Std. } \\
\text { Error }\end{array}$ & Beta & & \\
\hline \hline (Constant) & -0.085 & 0.008 & & -10.356 & 0 \\
\hline Rm-Rf & 0.01 & 0.008 & 0.138 & 0.889 & 0.379 \\
\hline SMB & 0.00 & 0.003 & -0.201 & -1.387 & 0.172 \\
\hline HML & 0.00 & 0.003 & 0.046 & 0.297 & 0.768 \\
\hline
\end{tabular}

Source: Author's construction

\section{Conclusions}

The study investigated the validity of the Fama and French three-factor model (1993) using monthly data for a sample of 50 firms listed on the EGX from January 2014 to December 2018. This involved examining the statistical significance of the explanatory variables of the model; market, size, and value premiums. The study used the same methodology as Fama and French (1993) to construct six portfolios ( $\mathrm{SL}, \mathrm{SM}, \mathrm{SH}, \mathrm{BL}, \mathrm{BM}, \mathrm{BH}$ ) based on the intersection of the tow size and three $B E / M E$ portfolios. Based on our statistical results, this study found no evidence supporting the ability of Fama and French three-factor model (1993) to provide a suitable explanation for the excess stock returns in the EGX; additionally, the market risk premium is not a determinant of the excess stock returns. Also, the study concluded that there was no small firm effect, and the book-to-market ratio effect does not exist in the EGX.

There are some explanations for why Fama and French three-factor model (1993) for the EGX does not show statistical significance. One of the reasons is the political fluctuations that the country witnessed during the study period, as these fluctuations began during the January revolution in 2011, which witnessed the change of the political system in Egypt. These fluctuations extended to include most of the study periods. This led to negative effects on the financial and economic indicators and the security situation in Egypt. The low liquidity in the market, taxes imposed on the EGX transactions and the decrease in the number 
of investors also have an important role negatively affecting the performance of stocks.

The results of the study contribute to the literature of asset pricing models. This study also attempts to find out the applicability of these models in the financial markets and their effectiveness in explaining the returns of a stock. The study results have important implications for the practice, especially for investors who want to create suitable portfolios based on return and risk. Through the results of the study, we notice that the large stock portfolios generate higher returns than small-size portfolios, although this result is inconsistent with the findings of Fama and French (1993).

Future studies may include periods for more than 5 years and may include a larger sample size. It is also possible to add other factors to the model and study their effect on explaining the expected return. The model can be tested at the sectoral level, where stocks can be divided into subsectors to capture the effects of the three risk factors of the Fama and French three-factor model (1993) more precisely on the sector base. Additionally, the validity of the Fama and French three-factor model (1993) can be tested against the CAPM on the EGX, which can lead to more efficiently constructed portfolios.

Although the three-factor model cannot explain excess stock returns in the EGX, it is still one of the most important asset pricing models in financial literature.

\section{References}

Alqisie, A. and Alqurran, T. (2016). Validity of Capital Assets Pricing Model (CAPM) (Empirical Evidences from Amman Stock Exchange). Journal of Management Research, 8(1), pp. 207-223.

Banz, R. W. (1981). The relationship between return and market value of common stocks. Journal of Financial Economics, 9(1), pp. 3-18. https://doi:10.1016/0304$\underline{405 \times(81) 90018-0}$

Chen, N. F., Roll, R. and Ross, S. (1986). Economic Forces and the Stock Market. the Journal of Business, 59(3), pp. 383-403.

Daniel, K. and Titman, S. (1997). Evidence on the Characteristics of Cross Sectional Variation in Stock Returns. The Journal of Finance, 52(1), pp. 1-33. https://doi:10.1111/j.1540-6261.1997.tb03806.x

Dirkx, P. and Peter, F. J. (2020). The Fama-French Five-Factor Model Plus Momentum: Evidence for the German Market. Schmalenbach Business Review, pp. $1-24$.

Fama, E. F. and French, K. R. (1992). The cross-section of expected stock returns. The Journal of Finance, 47(2), pp. 427-465.

Fama, E. F. and French, K. R. (1993). Common risk factors in the returns on stocks and bonds. Journal of Financial Economics, 33(1), pp. 3-56. https://doi.org/10.1016/0304-405x(93)90023-5 
Fama, E. F. and French, K. R. (1995). Size and Book-to-Market Factors in Earnings and Returns. The Journal of Finance, 50(1), pp. 131-155. https://doi.org/10.1111/j.1540-6261.1995.tb05169.x

Foye, J. (2016). A new perspective on the size, value, and momentum effects. Review of Accounting and Finance, 15(2), pp. 222-251. https://doi.org/10.1108/raf-05-2015-0065

Gaunt, C. (2004). Size and book to market effects and the Fama French three factor asset pricing model: Evidence from the Australian stockmarket. Accounting and Finance, 44(1), pp. 27-44. https://doi.org/10.1111/j.1467-629x.2004.00100.x

Hussain, S. and UI Islam, K. (2017). Is the Capital Asset Pricing Model valid in the Indian context? Pacific Business Review International, 9(7), pp. 115-124.

Khudoykulov, K., Khamidov, O. and Aktamov, A. (2015). Testing Capital Asset Pricing Model (CAPM) on the Emerging Markets of the Europe. Spanish Journal of Rural Development, pp. 1-8. https://doi.org/10.5261/2015.gen3.01

Lakonishok, J., Shleifer, A. and Vishny, R. W. (1994). Contrarian Investment, Extrapolation, and Risk. The Journal of Finance, 49(5), pp. 1541-1578. https://doi.org/10.1111/j.1540-6261.1994.tb04772.x

Lintner, J. (1965). The Valuation of Risk Assets and the Selection of Risky Investments in Stock Portfolios and Capital Budgets. The Review of Economics and Statistics, 47(1), pp. 13-37. https://doi.org/10.2307/1924119

Markowitz, H. (1952). Portfolio Selection. The Journal of Finance, 7(1), pp. 7791. https://doi:10.1111/j.1540-6261.1952.tb01525.x

Mazviona, B. W. and Nyangara, D. (2014). Does firm size affect stock returns? Evidence from the Zimbabwe Stock Exchange. International Journal of Business and Economic Development (IJBED), 2(3), pp. 13-17.

Mehta, K. and Chander, R. (2010). Application of Fama \& French Three Factor Model and Stock Return Behavior in Indian Capital Market. Asia Pacific Business Review, 6(4), pp. 38-56. https://doi.org/10.1177/097324701000600405

Mohanty, P. (2002). Evidence of Size Effect on Stock Returns in India. Vikalpa: The Journal for Decision Makers, 27(3), pp. 27-38. https://doi: 10.1177/0256090920020304

Novak, J. and Petr, D. (2011). CAPM Beta, Size, Book-to-Market, and Momentum in Realized Stock Returns. Finance a Uver: Czech Journal of Economics \& Finance, 61(1), pp. 447-460.

Ragab, N. S., Abdou, R. K. and Sakr, A. M. (2019). A Comparative Study between the Fama and French Three-Factor Model and the Fama and French Five-Factor Model: Evidence from the Egyptian Stock Market. International Journal of Economics and Finance, 12(1), 52-69. https://doi.org/10.5539/ijef.v12n1p52 
Reinganum, M. R. (1981). The Arbitrage Pricing Theory: Some Empirical Results. The Journal of Finance, 36(2), pp. 313-321. https://doi:10.1111/j.15406261.1981.tb00444.x

Ross, S. A. (1976). The arbitrage theory of capital asset pricing. Journal of Economic Theory, 13(3), pp. 341-360. https://doi:10.1016/0022-0531(76)90046$\underline{6}$

Shaker, M. A. and Abdeldayem, M. M. (2018). Examining asset pricing models in emerging markets: Evidence from Egypt. Corporate Ownership and Control, 16(1), pp. 50-57. https://doi.org/10.22495/cocv16i1art6.

Shaker, M. A. and Elgiziry, K. (2014). Comparisons of Asset Pricing Models in the Egyptian Stock Market. Accounting and Finance Research, 3(4), pp. 24-30. https://doi.org/10.5430/afr.v3n4p24

Sharpe, W. F. (1964). Capital Asset Prices: A Theory of Market Equilibrium under Conditions of Risk. The Journal of Finance, 19(3), pp. 425-442. https://doi: $10.2307 / 2977928$

Wang, W.G. (2018). The Variation of Fama-French Three-Factor Beta Risks by Interval Test in Taiwan Stock Market: Theory and Evidence, International Research Journal of Finance and Economics, 165, pp. 90-109. 